23. Temkin I. O., Klebanov D. A., Deryabin S. A., Konov I. S. Method of determining the state of the haul road career in the management of the interaction between robotic elements of the mining transportation complex. Mining journal. 2018. No.1. pp. 78-82.

24. Prokofeva E. N., Vostrikov A. V., Fernandez E., Borisov N. Navigation satellite systems as the audit foundation for mining companies. Eurasian Mining. 2017. No. 1. P. 30-32. DOI: 10.17580/em.2017.01.08

25. Satellite monitoring and geospatial solutions Available at: https://sovzond.ru/ (accessed: 21.11.2019).

26. Planet Labs Inc. Planet Imagery Product Specifications, August 2019. Available at: https://planet.com (accessed 30.08.2019).

27. Digital Earth Africa (2019). Open Data Cubes. Available at: https://www.digitalearthafrica.org/. (accessed: 15.11.2019).

28. 2019 Kenya National Housing and Population Census: Vol. I: Population by County and Sub-County. Kenya National Bureau of Statistics - KNBS. Nairobi, 2019.

29. Reich C., Schatz M., Zsak G. World Mining Data 2018. Vol. 33: Iron and Ferro Alloy Metals Non-ferrous Metals, Precious Metals, Industrial Minerals, Mineral Fuels. Vienna: Federal Ministry of Sustainability and Tourism, 2018.

30. Adero N. J. Redressing the nexus of human rights and mining in Kenya using geospatial models. Book of Abstracts of the
BHT 2018: Future Materials - Safe Resources Supply - Circular Economy and the $3^{\text {rd }}$ Interdisciplinary Colloquium and PhD Conference on the Social Responsibility of Science and Scientists. Freiberg, Germany, 6-7 June, 2018. pp. 12-13.

31. Trubetskoy K. N., Galchenko Yu. P. Geoecology of Subsoil Development and EcoGeotechnologies of Mineral Mining. Moscow: Nauchtekhlitizdat, 2015.

32. Rylnikova M. V., Galchenko Yu. P. Renewable Sources of Energy in Integrated Subsoil Development. Moscow : IPKON RAS, 2015.

33. Trubetskoy K. N., Galchenko Yu. P., Eremenko V. A. Fundamentals of converging mining technologies in integrated development of mineral resources of lithosphere. IOP Conference Series: Earth and Environmental Science. 2018. Vol. 134(1). 012064.

34. Rylnikova M., Ainbinder I., Radchenko D. Role of Safety Justification of Mining Development for the Regulatory Framework Formation and Mineral Resources Management. E3S Web of Conferences. 2018. Vol. 41. 01033. DOI: 10.1051/ e3sconf/20184101033

35. Kolosov V., Medvedev A., Zotova M. Comparing the development of border regions with the use of GIS (the case of Russia). Geographia Polonica. 2018. Vol. 91, No. 1. pp. 47-61. EM

UDC 622.85

V. V. KHAUSTOV ${ }^{1}$, Doctor of Geologo-Mineralogical Sciences, Professor

I. M. IGNATENKO ${ }^{1}$, Candidate of Engineering Sciences, Associate Professor, ignatenko i@bsu.edu.ru

A. V. SHLEENKO ${ }^{2}$, Candidate of Sciences, Associate Professor

E. A. ERMOLOVICH ${ }^{1}$, Doctor of Engineering Sciences, Professor

${ }^{1}$ Belgorod State University, Belgorod, Russia

${ }^{2}$ Southwest State University, Kursk, Russia

\title{
BIOCHEMICAL IMPACT OF THE TYRNYAUZ FIELD DEVELOPMENT ON THE BAKSAN RIVER
}

In recent decades, heavy metals as environmental pollutants are of increasing concern. Heavy metals are proved to be the main pollutants of the atmosphere, groundwater and surface water, soil cover, etc. Unlike organic pollutants decomposable in a varying degree, heavy metals are incapable to disintegrate but only re-spread among different components of water ecosystems-water, suspended solids, bottom sediments and biota, and, therefore, they should be considered as constantly present in ecosystems [1]. Increasing concentrations of heavy metals in various natural objects is detrimental to the living world, therefore, identifying sources of pollution, their distribution, developing methods to combat
The influence of the Tyrnyauz tungsten-molybdenum plant on the water ecosystem of the Baksan River is investigated. The anomalies cased by mining activities in groundwater and surface waters, in suspended matter and in bottom sediments in long sections of the river valley are revealed. The relationship between the protein in bottom sediments and the concentrations of some heavy metals is determined and explained.

Keywords: heavy metals, pollution, water ecosystem, bioindication, protein of bottom sediments. DOI: $10.17580 / \mathrm{em} .2020 .01 .15$

pollution seems to be a very urgent task both in general and for specific regions where these processes have their own specifics.

In this regard, the topic of choosing the most informative indicators in assessing the extent of technogenesis is also relevant. There is a need to study the geochemical conditions of migration of pollutants and their role in the functioning 
of natural ecosystems, due to the growing anthropogenic impact, primarily, in development of large mineral deposits. The processes of mining-induced technogenesis are particularly active in mining areas of heavily mountainous terrain, with the formation of large-scale halos of induced dispersion of typomorphic elements.

Mines are among the most powerful environmental contaminators by heavy metals, and the Tyrnyauz tungstenmolybdenum plant (hereinafter referred to as TTMP) is not an exception in this respect. Anomalies caused by mining activities in underground and surface waters, bottom sediments and soils, covering very long sections of the Baksan River Valley, prove this.

The intense river pollution in the area of TTMP began since the time of the Tyrnyauz field development. Prior to this period, the Kabardino-Balkaria rivers and, in particular, the Baksan River were the main spawning site for Terek salmon, stellate sturgeon, carp, and other species of fish [2]. In 1958, erosion of old tailings at TTMP resulted in mass killing of fish for a distance of tens kilometers from the place of erosion [3]. The situation in fisheries was aggravated by the construction of the Pavlodol dam on the Terek River, since valuable species of fish disappeared above it in all rivers of the basin, which caused significant damage to their populations in the Caspian Sea [4].

The development of the Tyrnyauz field led to a noticeable increase in the solid runoff of the Baksan River: after industrial drains began to be actively discharged into the river (midfifties), it increased about 3-5 times (data of the Gipronikel Institute). This significantly deteriorated the use conditions of river water for drinking and domestic water supply, and settlements located in the middle and lower reaches of the river were forced to switch to groundwater.

The chemical quality of river waters clearly reflects the lithological and geochemical features of rocks in adjacent structural and formation zones of the northern slope of the Central Caucasus, which cross the riverbed. The mining areas are characterized by space-time variation in the acidbase indicator of the surface of the water, which leads to significant restructuring of mitigation conditions of chemical elements. All tributaries of the Baksan River above the Tyrnyauz field is characterized by a neutral reaction ( $\mathrm{pH} 7.2-7.5)$. There is a tendency towards an increase in $\mathrm{pH}$ value and in the concentration of bicarbonate ions in the area of the quarry and waste dumps, and especially clearly in the areas where the clarified waters discharge from the tailings dump. This leads to an increase in the mobility of some elements, in particular, molybdenum in the corresponding sections of the river (the migration ability of molybdenum increases with increasing $\mathrm{pH}$ ).

It is a common knowledge that substances, including pollutants, mitigate in rivers as both dissolution and suspension. Conventionally, the quality of the water environment contaminated with heavy metals was assessed mainly from the comparison of gross heavy metals with MPC values. However, the studies have shown [1. p. 123] that such assessment is unreasonable and the gross content of heavy metals is unsuitable for these purposes, since "... their biological activity and chemical reactivity in natural waters is governed to a large extent by their state-a whole set of coexisting physical and chemical forms." At the same time, dissociated aquatic ions of heavy metals and some hydrocomplexes are the most toxic to water organisms due to certain penetrability through cell membrane
Table 1. The changes in alkaline-acid conditions and the content of $\mathrm{HCO}_{3}$ ion ( $\mathrm{mg} / \mathrm{I}$ ) in river waters along the Baksan River

\begin{tabular}{|l|c|c|c|c|}
\hline \multirow{2}{*}{\multicolumn{1}{|c|}{ Water point location }} & \multicolumn{2}{|c|}{ Baksan River } & \multicolumn{2}{c|}{ Inflows } \\
\cline { 2 - 5 } & $\mathrm{pH}$ & $\mathrm{HCO}_{3}$ & $\mathrm{pH}$ & $\mathrm{HCO}_{3}$ \\
\hline Terskol village & 7.4 & 55.2 & 7.2 & 64.7 \\
\hline Verkhni Baksan village & 7.0 & 70.1 & 6.8 & 82.8 \\
\hline Chelmas & 7.5 & 60.9 & 7.6 & 75.3 \\
\hline Southern outskirts of Tyrnyauz & 7.8 & 61.2 & 7.1 & 42.2 \\
\hline TTMP plant & 7.8 & 109.0 & 7.6 & 58.4 \\
\hline $\begin{array}{l}\text { 1 km above the discharge of } \\
\text { clarified tailings waters }\end{array}$ & 8.0 & 61.4 & - & - \\
\hline $\begin{array}{l}\text { The discharge of clarified } \\
\text { tailings waters }\end{array}$ & 8.6 & 176.3 & 7.6 & 85.3 \\
\hline $\begin{array}{l}\text { 1 km below the discharge of } \\
\text { clarified waters }\end{array}$ & 8.2 & 167.1 & 7.5 & 98.4 \\
\hline Bedik village & 7.8 & 122.9 & 7.6 & 110.2 \\
\hline Lashkuta village & 7.5 & 79.5 & 7.6 & 85.1 \\
\hline Zayukovo settlement & 7.5 & 91.6 & 7.5 & 62.3 \\
\hline Kizburun-1 settlement & 7.3 & 92.1 & 7.5 & 111.4 \\
\hline Baksan & 7.3 & 95.5 & 7.5 & 128.2 \\
\hline
\end{tabular}

[5]. According to P. N. Linnik [1], the correct assessment of the toxicity level of the water environment, determined by compounds of heavy metals, is possible only on the basis of data on the content of the dissociated aqua ions in water. In these studies, we used the results on the concentration of free ions in river water obtained by colorimetric methods most suitable for these purposes.

Statistical parameters of the distribution of microcomponents in modern bottom sediments of the Baksan River are given in Table 2. It turns out that the distribution of the typomorphic elements of the Tyrnyauz field is satisfactory enough in accordance to the usual law of distribution. Deviations of the asymmetry estimate from zero to the positive side for molybdenum, tin, chromium, bismuth, zirconium indicate the presence of abnormally high concentrations of these elements in the sample. The distribution of the abovementioned elements is characterized by more noticeable variations, which is a characteristic feature of the anthropogenic dispersion flux. The close correlation (Table 3 ) points at the paragenicity of accumulation of typomorphic elements-molybdenum, tungsten, tin, chalk, bismuth, lead, chromium, and once again confirms that the degree of separation of these elements in bottom sediments is small. The distribution of these elements along the river is highly consistent and no sharp differentiation of their associations is observed.

Associations and concentrations of chemical elements in bottom sediments indicate that scattering fluxes in modern formations of the Baksan River have significant size and high content of a wide group of elements with sharply varying distributions along the profile. The formed zones of intense pollution in the bottom sediments of the Baksan River can persist quite long (tens and hundreds of years), and are a potentially hazardous source of secondary pollution of the aquatic environment $[6,7]$.

The changes in the microcomponent composition of the Baksan River waters are shown in the figure. It is easy to see that the natural association of elements and their ratios undergo sharp deformation in the area of the deposit 
Table 2. Statistical data on distribution of microcomponents in modern bottom sediments of the Baksan River (No. = 32)

\begin{tabular}{|c|c|c|c|c|c|c|c|c|}
\hline No. & Metals & Minimum & Maximum $\mathrm{mkg} / \mathrm{g}$ & Average & Standard deviation & Variation & Asymmetry & Kurtosis \\
\hline 1 & $\mathrm{~W}$ & 1 & 800 & 334.43 & 294.42 & 0.881 & 0.726 & -1.216 \\
\hline 2 & $\mathrm{Mo}$ & 5 & 500 & 120.31 & 131.64 & 0.094 & 1.671 & 2.030 \\
\hline 3 & $\mathrm{~Pb}$ & 20 & 150 & 87.50 & 32.96 & 0.376 & 0.143 & -0.069 \\
\hline 4 & $\mathrm{Mn}$ & 200 & 1500 & 728.12 & 337.62 & 0.463 & 0.468 & -0.610 \\
\hline 5 & $\mathrm{Sn}$ & 5 & 35 & 12.00 & 7.91 & 0.659 & 1.489 & 1.724 \\
\hline 6 & $\mathrm{Ti}$ & 1500 & 5000 & 3000.00 & 1224.74 & 0.408 & 0.484 & -1.322 \\
\hline 7 & $\mathrm{Cu}$ & 5 & 150 & 66.87 & 36.46 & 0.545 & 0.472 & -0.497 \\
\hline 8 & $\mathrm{Zn}$ & 20 & 150 & 67.81 & 37.01 & 0.545 & 0.379 & -0.761 \\
\hline 9 & $\mathrm{Cr}$ & 20 & 150 & 55.00 & 35.26 & 0.641 & 1.312 & 0.800 \\
\hline 10 & $\mathrm{Be}$ & 1 & 3 & 1.87 & 0.80 & 0.751 & 0.201 & -1.531 \\
\hline 11 & $\mathrm{Sc}$ & 2 & 20 & 8.31 & 6.24 & 0.385 & 0.670 & -1.018 \\
\hline 12 & $\mathrm{Bi}$ & 1 & 35 & 6.31 & 8.74 & 0.423 & 2.169 & 4.362 \\
\hline 13 & $\mathrm{Ni}$ & 10 & 50 & 26.87 & 11.38 & 0.899 & 0.136 & -1.102 \\
\hline 14 & $\mathrm{Zr}$ & 80 & 2000 & 592.50 & 532.88 & 0.285 & 1.236 & 0.782 \\
\hline 15 & $\mathrm{Sr}$ & 350 & 800 & 575.00 & 164.31 & 0.295 & 0.427 & -1.437 \\
\hline 16 & $\mathrm{Ba}$ & 50 & 200 & 134.37 & 39.66 & 0.363 & -0.208 & -0.594 \\
\hline 17 & $\mathrm{TP}$ & 7 & 94 & 52.62 & 19.14 & 0.429 & -0.131 & 0.767 \\
\hline Note: $\mathrm{TP}-$ total protein & & & & & \\
\hline
\end{tabular}

Table 3. Correlation matrix of the content of chemical elements in the bottom sediments of the Baksan River (32 samples)

\begin{tabular}{|c|c|c|c|c|c|c|c|c|c|c|c|c|c|c|c|c|c|c|}
\hline \multirow{2}{*}{ No. } & \multirow{2}{*}{ Elements } & $\mathrm{TP}$ & $\mathrm{W}$ & $\mathrm{Mo}$ & $\mathrm{Pb}$ & $\mathrm{Mn}$ & $\mathrm{Sn}$ & $\mathrm{Ti}$ & $\mathrm{Cu}$ & $\mathrm{Zn}$ & $\mathrm{Cr}$ & $\mathrm{Be}$ & $\mathrm{Sc}$ & $\mathrm{Bi}$ & $\mathrm{Ni}$ & $\mathrm{Zr}$ & $\mathrm{Sr}$ & $\mathrm{Ba}$ \\
\hline & 1 & 2 & 3 & 4 & 5 & 6 & 7 & 8 & 9 & 10 & 11 & 12 & 13 & 14 & 15 & 16 & 17 \\
\hline 1 & $\mathrm{TP}$ & 100 & & & & & & & & & & & & & & & & \\
\hline 2 & $\mathrm{~W}$ & 47 & 100 & & & & & & & & & & & & & & & \\
\hline 3 & $\mathrm{Mo}$ & 37 & 43 & 100 & & & & & & & & & & & & & & \\
\hline 4 & $\mathrm{~Pb}$ & 12 & 53 & 65 & 100 & & & & & & & & & & & & & \\
\hline 5 & $\mathrm{Mn}$ & 9 & 41 & 64 & 25 & 100 & & & & & & & & & & & & \\
\hline 6 & $\mathrm{Sn}$ & 33 & 51 & 86 & 71 & 64 & 100 & & & & & & & & & & & \\
\hline 7 & $\mathrm{Ti}$ & 2 & 66 & 10 & 27 & 22 & 21 & 100 & & & & & & & & & & \\
\hline 8 & $\mathrm{Cu}$ & 53 & 62 & 50 & 43 & 44 & 53 & 25 & 100 & & & & & & & & & \\
\hline 9 & $\mathrm{Zn}$ & 6 & 38 & 39 & 46 & 39 & 45 & 38 & 64 & 100 & & & & & & & & \\
\hline 10 & $\mathrm{Cr}$ & 56 & 56 & 14 & -8 & 51 & 32 & 38 & 42 & 20 & 100 & & & & & & & \\
\hline 11 & $\mathrm{Be}$ & 26 & -7 & -25 & 11 & -56 & -19 & -16 & -2 & 1 & 3 & 100 & & & & & & \\
\hline 12 & $\mathrm{Sc}$ & 8 & 16 & 0 & -6 & -13 & -3 & 41 & -27 & -30 & 8 & -21 & 100 & & & & & \\
\hline 13 & $\mathrm{Bi}$ & 62 & 59 & 44 & 33 & 53 & 62 & 19 & 65 & 39 & 80 & 19 & -20 & 100 & & & & \\
\hline 14 & $\mathrm{Ni}$ & 21 & 49 & 70 & 59 & 65 & 74 & 23 & 35 & 65 & 39 & 0 & -14 & 58 & 100 & & & \\
\hline 15 & $\mathrm{Zr}$ & 21 & 51 & 15 & 4 & 11 & 14 & 77 & 0 & -11 & 33 & -30 & 67 & 5 & 0 & 100 & & \\
\hline 16 & $\mathrm{Sr}$ & 25 & 30 & 56 & 46 & 19 & 43 & 34 & 8 & -6 & 6 & -15 & 55 & 10 & 16 & 57 & 100 & \\
\hline 17 & $\mathrm{Ba}$ & 29 & 32 & -22 & 22 & -28 & 11 & 24 & 7 & -18 & 25 & 24 & 41 & 29 & -18 & 24 & 19 & 100 \\
\hline Note: For convenience the correlation coefficients are multiplied by 100. & & & & & & & \\
\hline
\end{tabular}

(cross-section I), when the products of leaching waste dumps (Maly and Bolshoi Mukulan streams) and drainage waters of the deposit (Chilmian stream and the Kamyk River) enter river waters [6]. In this section, the concentrations of molybdenum and arsenic exceed MPC for drinking water. The most acute pollution of river waters with heavy metals is recorded in the area of the main tailings of TTMP ( $15 \mathrm{~km}$ below the field along the Baksan River, cross-section II), which indicates the maximum contribution of the clarified waters of the tailings to the total pollution of the river. There are already three elements-molybdenum, tungsten and arsenic-exceed MPC, and antimony is at the level of MPC. This observation crosssection characterizes the total input of ore-bearing elements from various objects of TTMP and shows that typomorphic elements of the Tyrnyauz deposit exceed the maximum permissible concentration in river waters. Downstream in the area of intensive feeding of the river with underground, mainly karst waters (cross-section III) and further in the area of intensive river water analysis for irrigation of agricultural land ( $40 \mathrm{~km}$ below the field, cross-section IV), the concentration of many microcomponents under study, only tungsten is at the level of MPC. 

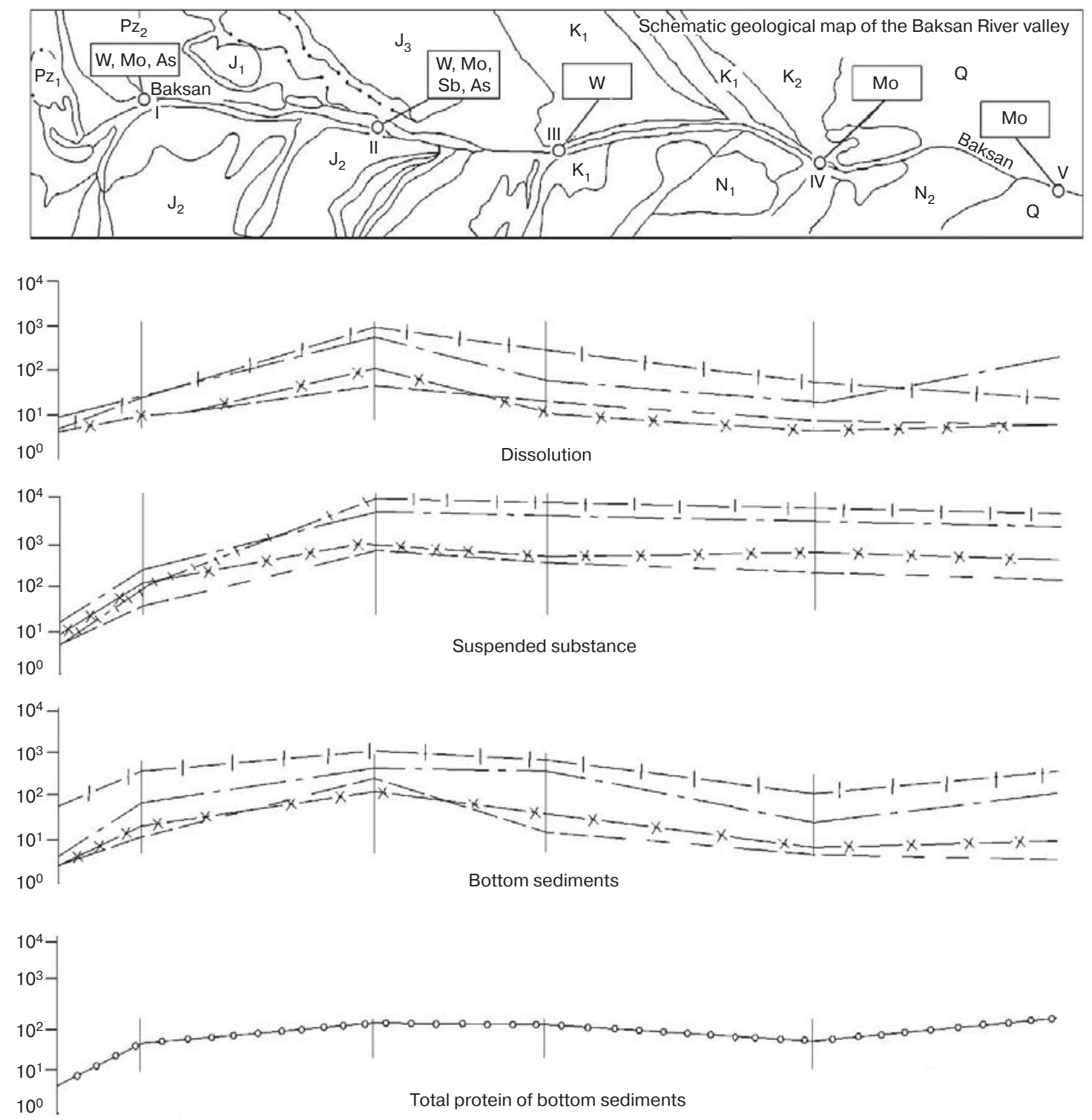

Legend

\begin{tabular}{|c|c|c|c|}
\hline$-\cdot-$ & Molybdenum & $\mathrm{I}_{\mathrm{O}}$ & Observation cross-section \\
\hline$-1-$ & Tungsten & Mo & Elements exceeding MPC in river waters \\
\hline$\rightarrow-x$ & Arsenic & & Tyrnauz field \\
\hline--- & Antimony & & Tailings pond \\
\hline
\end{tabular}

Figure. Distribution of typomorphic elements of the Tyrnyauz field in various components of water ecosystem of the Baksan River

Cross-section $\mathrm{V}(60 \mathrm{~km}$ below the field) is located at the exit of the Baksan River to the flat terrain, consequently, at the place of changing the hydrological regime of the watercourse. Here, the concentrations and ratios of the studied oreogenic metals are close to natural (background). However, against the general trend towards a decrease in the concentration of heavy metals, the molybdenum content sharply increases [7]. In this case, in the absence of any other real sources of molybdenum, it enters from the bottom sediment of the river (desorption), which means the secondary pollution of the water environment-the phenomenon widely discussed in the literature [8].
The quality control of natural waters (more broadly, water ecosystems) is based primarily on the use of hydrochemical methods, as well as on bioassay and bioindication methods.

Deliberately avoiding the discussion on effectiveness and adequacy of hydrochemical methods with all positive characteristics inherent in them, we specify their main problems: obvious insufficiency (the number of pollutants is estimated at several tens of thousands, and a little more than a thousand sanitary and hygienic and six hundred fishery standards have been developed, of which two thirds are not provided with analytical methods); MPC system is a complex of differentiated assessments which neglect the synergistic and antagonistic 
effects of mixtures of pollutants; integration of the results of analytical control with the help of the calculated total pollution index (TPI) lacks a strict scientific basis. Furthermore, biotesting methods fail to give unambiguous results, since they reflect the reaction to contamination of test organisms in laboratory conditions, which not always coincides with the response of the biota of a real object.

As an alternative to the noted methods, approaches based on the biochemical assessment of the water cenoses productivity have appeared in recent decades. These methods enable integrated characterization the ecosystem response to pollution, and the use of these methods in combination with hydrochemical techniques can significantly increase information content of geoecological studies in general [9].

In order to clarify the biogeochemical reactions of living organisms to river pollution, microorganisms of bottom sediments were selected. Representatives of the microworld are the most sensitive and universal of all known bioindicators, since they react very quickly to changes in external conditions. To find out the effect of heavy metals on microorganisms, their biomass was determined. The biomass of microflora of bottom sediments was estimated by the indicator of total protein (TP). The concentration of cell protein of microorganisms is highly stable and amounts to $50 \%$ of dry biomass [10]. For the analysis of protein in bottom sediments, the Nizharadze-Pushnova method based on the Bradford reaction was used [11].

It is found that TP distribution stably correlates with the distribution of a number of heavy metals-W, Mo, As, Pb, Sb, etc. (three year-long observation data). Moreover, the stable positive correlation dependence is established between these indicators: TP / Mo-0.89, TP / W-0.66.

A probable explanation of the established spatial relationship between TP and heavy metals is that heavy metals having high electronegativity have an affinity for the functional groups of proteins that these metals block to form chelate complex compounds. The formation of strong compounds of heavy metals with polar groups of proteins distorts the system of hydrogen and ionic bonds of the native protein molecule, i.e. it causes protein denaturation [12]. The latter is associated with the loss of biological activity, the destruction of hydration shells, a decrease in solubility, that is, it contributes to the accumulation of protein in the bottom sediments of the river.

Thus, the accumulation of protein in the bottom sediments of the Baksan River is caused by the toxicity of aquatic microorganisms with heavy metals, binding of the protein of dead cells with metal ions to chelate complexes, and by the accumulation of the latter in the bottom sediments of the river. It is important to understand that chelates are of particular environmental danger, since they differ from other forms by their capability of rapid geochemical transformation under the influence of external factors, as a result of which new compounds can be formed, which are sometimes more toxic than the initial materials. The interrelation of the spatial distribution of protein and toxicant concentrations, as well as the discovery of the mechanism of their accumulation in bottom sediments, made it possible to determine the spectrum of pollutants which induce pronounced negative reaction of the Baksan River ecosystem.

The positive correlation between the distribution of TP and heavy metals allowed us to describe their relationship by linear regression equations:
$\mathrm{TP}=0.03 \mathrm{~W}+42.26 ; \mathrm{TP}=0.05 \mathrm{Mo}+46.03 ; \mathrm{TP}=0.28 \mathrm{Cu}+$ +33.71 ;

$$
\mathrm{TP}=0.31 \mathrm{C} r+35.66 ; \mathrm{TP}=0.36 \mathrm{Bi}+31.27
$$

In conclusion, it should also be noted that such equations open up prospects for using TP as an integral indicator of pollution of bottom sediments of watercourses in a wide range of natural landscape conditions [13]. This example proves the effectiveness of the use of the protein method and demonstrates its advantages, namely, swiftness and cost-effectiveness (analysis of samples for TP content is $50-70 \%$ cheaper than traditional chemical and microbiological analyzes, and its use increases the labor productivity of a laboratory worker by 3-4 times). Identification of the forms of protein accumulation in the bottom sediments of the Baksan River can significantly reduce the error in the determination of heavy metals using an integral indicator-TP.

References

1. Linnik P. N., Nabivanets Yu. B. Forms of metal migration in fresh surface waters. Leningrad : Gidrometeoizdat, 1986. 271 p.

2. Krasnozhen A. M. Fishes of natural reservoirs of KabardinoBalkaria and their protection. Protection and rational use of soils, subsoil and water resources of Kabardino-Balkaria. Nalchik, 1977. pp. 90-94.

3. Parfenik A. N. Fishes of the regions of the Kabardino-Balkaria Autonomous Soviet Socialist Republic and measures to preserve their stocks. Nature of Kabardino-Balkaria and its protection. Nalchik : Kabardino-Balkaria knish. Izd., 1966. Iss. 1. pp. 68-86.

4. Water resources of the Terek River basin and their use. Rostov-on-Don : Yuzhgidrovodkhoz, 1983. $239 \mathrm{p}$.

5. Luoma S. N. Bioavailability of trace metals to aquatic organisms-a review. The Science of the Total Environment. 1983. Vol. 28, Iss. 1-3. pp. 1-22.

6. Khaustov V. V. Groundwater and deep geodynamics of Tyrnyauz. Kursk : KurskGTU, 2009. 180 p.

7. Khaustov V. V. Groundwater formation of the Tyrnyauz tungsten-molybdenum deposit and pollution protection of the Baksan River Basin. Synopsis of Cand. Geol.-Min. Sci. Thesis. Leningrad : LGU, 1990. 22 p.

8. Moore J. V., Ramamurti S. Heavy metals in natural waters. Moscow : Mir, 1987. 285 p.

9. Nizharadze T. N., Tomilin A. M., Lazdovskaya M. A. Express examination of violations of ecological balance in soils and waters. Geochemical methods in environmental studies. Moscow : IMGRE, 1992. pp. 35-41.

10. Nizharadze T. N., Pushnova E. A. et al. Quantitative accounting of the influence of the vital activity of microorganisms on the physical and mechanical properties of clayed soil. Methodical guide. Leningrad : LGU, 1988. 24 p.

11. Nizharadze T. N., Pushnova E. A. Method of determining the degree of gleying of rock. Patent USSR, No. 01404940. Applied: 27.01.1986. Published: 23.06.1988. Bulletin No. 23.

12. Tomilin A. M. Assessment of the ecological state of water bodies using protein criteria. Synopsis of Cand. Eng. Sci. Thesis. Saint Petersburg: SPbGGI, 1990. $19 \mathrm{p}$.

13. Khaustov V. V., Khaustova T. V. An economic method for bioindication of pollution of bottom sediments in rivers by heavy metals. Modern environmental problems in the provinces. Abstract. Kursk : Ionor, 1995. pp. 253-255. ․ㅣ 